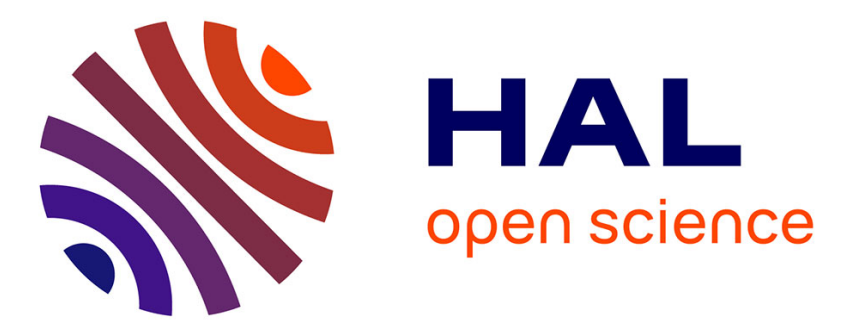

\title{
Caesium-137 in sandy sediments of the River Loire (France): Assessment of an alluvial island evolving over the last 50 years
}

Sébastien Détriché, Stéphane Rodrigues, Jean-Jacques Macaire, Philippe Bonté, Jean-Gabriel Bréhéret, Jean-Paul Bakyono, Philippe Jugé

\section{To cite this version:}

Sébastien Détriché, Stéphane Rodrigues, Jean-Jacques Macaire, Philippe Bonté, Jean-Gabriel Bréhéret, et al.. Caesium-137 in sandy sediments of the River Loire (France): Assessment of an alluvial island evolving over the last 50 years. Geomorphology, 2010, 115, pp.11-22. 10.1016/j.geomorph.2009.07.003 . insu-00442620

\section{HAL Id: insu-00442620 \\ https://hal-insu.archives-ouvertes.fr/insu-00442620}

Submitted on 24 Dec 2009

HAL is a multi-disciplinary open access archive for the deposit and dissemination of scientific research documents, whether they are published or not. The documents may come from teaching and research institutions in France or abroad, or from public or private research centers.
L'archive ouverte pluridisciplinaire HAL, est destinée au dépôt et à la diffusion de documents scientifiques de niveau recherche, publiés ou non, émanant des établissements d'enseignement et de recherche français ou étrangers, des laboratoires publics ou privés. 


\title{
Caesium-137 in sandy sediments of the River Loire (France): Assessment of an alluvial island evolving over the last 50 years
}

\author{
Sébastien Détriché a, Stéphane Rodrigues ${ }^{a}$, Jean-Jacques Macaire ${ }^{a}$, Philippe Bontéb, \\ Jean-Gabriel Bréhéret ${ }^{\mathrm{a}}$, Jean-Paul Bakyono and Philippe Jugéc
}

${ }^{a}$ Université François-Rabelais de Tours, UMR CNRS 6113 ISTO-Tours, UFR Sciences et

Techniques, Parc Grandmont, 37200 Tours, France

${ }^{\mathrm{b}}$ UMR CNRS-CEA 1572, Laboratoire des Sciences du Climat et de l'Environnement (LSCE), CNRS, Domaine du CNRS, Bat. 12, 91198 Gif-sur-Yvette, France

${ }^{\mathrm{c}}$ CETU-Elmis ingénieries, Antenne Universitaire en Val de Vienne, 11 quai Danton, 37500 Chinon, France

\begin{abstract}
Recent sedimentological and morphological evolution of an island in the River Loire (France) was investigated using the ${ }^{137} \mathrm{Cs}$ method. This study describes the morphological adjustment of the island in the last 50 years, which corresponds to the increased bed incision of this sandy, multiple-channel environment because of, among other things, the increase in sediment extraction up to 1995.

The results show that some ${ }^{137} \mathrm{Cs}$ can be retained by sandy particles, potentially in clay minerals forming weathering features included in detrital sand grains. From a morphological perspective, significant lateral erosion can be observed in the upstream part of the island, while a weak lateral accretion occurs in its downstream section. Data about ${ }^{137} \mathrm{Cs}$ and aerial photographs show that the morphology of the island margins has undergone significant changes leading to a lateral migration, while the centre of the island has remained relatively stable or is slowly eroding. The migration of the island depends on: (1) the withdrawal of inherited preincision morphological units, such as levees, or the development of new units, such as a channel shelf; (2) water and sediment supply from surrounding channels during flood events; (3) preferential sediment trapping (20 mm year ${ }^{-1}$ ) from the presence of riparian vegetation on the bank of the secondary channel that is subject to narrowing. The sedimentological and morphological response of the island in the context of incision of the Loire river bed is expressed mainly by lateral migration and secondarily by a low vertical adjustment.
\end{abstract}

Keywords: ${ }^{137} \mathrm{Cs}$; Alluvial island; Sands; River Loire; Incision; Natural levee; Riparian vegetation; Floods

\section{Introduction}

Vegetated alluvial islands are one of the fundamental units of the river system often used to define fluvial patterns (e.g., braided, anastomosed, anabranching), although the distinction between bars and islands is subtle (Gurnell et al., 2001). The classification of multiplechannel rivers proposed by Nanson and Knighton (1996) and the observations of Wende and Nanson (1998) have highlighted the importance of sediment grain size, colonization of river beds by vegetation, and the stream power of side channels in the morphological evolution of anabranching rivers. The relatively simple concept of channel-floodplain interaction 
developed for small single-channel rivers is not easy to transpose to multiple-channel rivers, because of the hydrological and sedimentological functioning of channels splitting around islands and because of the feedback exerted by islands on flows.

Island formation and evolution within relatively large rivers result from interactions between erosion and aggradation processes such as mid-channel bar nucleation and fixing by inchannel vegetation ([Leopold and Wolman, 1957], [Church and Jones, 1982], [Osterkamp, 1998], [Kollmann et al., 1999], [Gurnell et al., 2001], [Nakayama et al., 2002], [Allain-Jegou, 2002] and [Rodrigues et al., 2007]) or excision of existing floodplain deposits ([Osterkamp, 1998] and [Gurnell et al., 2001]). Morphological evolution of alluvial islands has been documented on several river systems ([Nanson and Croke, 1992], [Gurnell et al., 2001], [Gurnell and Petts, 2002] and [Tooth and McCarthy, 2004]) and identified as a key parameter of morphological metamorphosis of alluvial systems. These processes are directly linked to river system characteristics (valley width, bed slope, sediment discharge), amplitude of flood events, type and degree of vegetation development, and/or human activities and disturbances ([Peiry et al., 1994], [Ward et al., 1999], [Kollmann et al., 1999] and [Gurnell and Petts, 2002]).

Islands and floodplains can also be regarded as potential recorders of the river-system evolution, especially in an environment affected by incision and colonization by plants ([Petts et al., 1989], [Hupp and Simon, 1991], [Bravard et al., 1997], [Tockner et al., 2000], [Piégay et al., 2000], [Steiger et al., 2001] and [Vautier et al., 2002]). This recording potential depends upon (i) fine sediment deposition and preservation, and (ii) alluvial vegetation, often used to investigate paleohydrology ([Sigafoos, 1964], [Hupp, 1988] and [Gottesfeld and JohnsonGottesfeld, 1990]) and associated sediment deposition. With regard to the latter point, floodplain sedimentation has been widely studied using radioisotope techniques such as ${ }^{137} \mathrm{Cs}$ and unsupported ${ }^{210} \mathrm{~Pb}$ to assess geomorphological changes and characterize accretion/erosion rates during the last 50 years ([McHenry et al., 1976], [Campbell et al., 1982], [Walling and Bradley, 1989], [Hasholt and Walling, 1992], [Walling and He, 1992], [Walling and He, 1993], [Walling and He, 1994], [Walling and He, 1997], [Goodbred and Kuehl, 1998], [Steiger et al., 2001], [Terry et al., 2002], [Thorndycraft et al., 2005], [Dion et al., 2005], [Terry et al., 2006] and [Soster et al., 2007]). Studies have generally been conducted on large lowland river floodplains where flood events are characterized by variable amplitude, quasi continuous sediment deposition for a long time (He and Walling, 1996), and settling of small particles favourable to retention of radionuclides ([Frissel and Penders, 1983], [Evans et al., 1983], [Livens and Rimmer, 1988] and [Walling et al., 1996]). However, the reliability of radionuclide geochronology methods for studying alluvial sediments formed by a mixture of fine (clayey-silty) to coarse (sandy-gravelly) particles has not been demonstrated except by Hasholt and Walling (1992) on a proglacial river in Greenland (west of Mitdualgkat Glacier) and Dion et al. (2005) on the Savannah River floodplain.

The River Loire (France) is a sandy-gravelly fluvial system characterized by multiple channels separated by relatively high islands colonized by floodplain vegetation. This river provides a valuable example of a rapidly evolving environment, specifically with regard to islands ([Gautier et al., 2005] and [Grivel, 2008]), as its main channel has lowered significantly over the last few decades. The morphological changes triggered by main channel incision have induced destabilization of dykes and bridges, disconnection of secondary channels, rapid colonization by woody vegetation, intense sediment aggradation in side channels, and decreased habitat diversity. One cause of this evolution is the significant increase in sediment extraction between 1950 and 1995 ([Dambre and Malaval, 1993] and 
[Belleudy, 2000]), a time period which can be documented by radioisotope techniques such as ${ }^{137}$ Cs.

The present study focuses on characterizing the geomorphological evolution of a vegetated island in the River Loire (France) over the last 50 years using the ${ }^{137} \mathrm{Cs}$ method. Two main questions were addressed: (i) Are ${ }^{137} \mathrm{Cs}$ techniques useful for studying sandy alluvial sediments? (ii) What was the morphological response of the vegetated island to flood events during the last 50 years in a human-influenced context? This is the first time that data about

${ }^{137} \mathrm{Cs}$ in the River Loire has been used to characterize recent sedimentary processes involved in fluvial island evolution.

\section{Study area and hydrology of the River Loire}

The Loire is the largest river in France (1020 km long) and drains a catchment area of $117,000 \mathrm{~km}^{2}$. Hydrology is characterized by variations between severe drought in summer and high-magnitude floods during winter and spring. High discharges are caused by intense rainfall from the Atlantic or storms in the upper mountainous reaches ([Dacharry, 1974] and [Duband, 1996]). At the Tours gauging station $(760 \mathrm{~km}$ from the source and $30 \mathrm{~km}$ upstream of the study site), the average discharge is $374 \mathrm{~m}^{3} \mathrm{~s}^{-1}$, and $\sim 1500 \mathrm{~m}^{3} \mathrm{~s}^{-1}$ for the 1- in 2-year flood (data from Diren Centre).

The Bréhémont site is located in the middle reaches of the Loire, $\sim 790 \mathrm{~km}$ downstream of the source (Fig. 1A, B). In this area, the valley is $3300 \mathrm{~m}$ wide, and the river flows through Cretaceous and Tertiary sedimentary rocks. Embankments built in the XIIth century in Anjou (Dion, 1961) and in the XIVth century in Touraine (Burnouf, 2001) have significantly reduced the width of the active area of the river, which at present flows in a narrow bed (700 m between embankments with a main channel width of $c a .175-300 \mathrm{~m}$ ). At the study site, the river bed is asymmetrical: the left side of the incised main channel located on the right bank fringes a network of relatively stable vegetated islands separated by secondary channels (or anabranches). Because of the incision of the main channel, the side channels are only inundated during floods and the islands are rarely submerged. The flooding of the secondary channels occurs when the discharge at the Langeais gauging station is $\sim 650 \mathrm{~m}^{3}$ $\mathrm{s}^{-1}$, while submersion of islands begins with a discharge of $\sim 2000 \mathrm{~m}^{3} \mathrm{~s}^{-1}$ (full submersion occurs for discharge $\sim 2300 \mathrm{~m}^{3} \mathrm{~s}^{-1}$; Fig. 1C). The discharge record at the Langeais gauging station shows an annual flood frequency with variable magnitudes characterizing episodic inundations of the islands (Fig. 1C). In the secondary channels, frequent submersion and moderate sediment reworking allows colonization by pioneer woody vegetation mainly composed of black poplars (Populus nigra L.). Softwood communities (namely Salix spp., Fraxinus spp., Ulmus spp., and Acer negundo) colonize the banks, and hardwood forests are found at the top of the islands (Cornier, 2002). At the study site, grassland on both Pallu and Férandière Islands provides evidence of former pastureland not used for agricultural activity since the 1950s. At their boundary, these two islands are delimited by a line of trees located at the top of the bank. The study was conducted on Pallu Island, which is bordered by the main channel to the north and the secondary channel A to the south (Fig. 1A). 


\section{Data sources, materials and methods}

\subsection{Topographic survey, field sampling and grain size analysis}

Five topographic transects were performed using a total station, and a topographic map of the island was obtained by combining topographic field surveys and airborne laser scanning data from the Diren Centre (LiDar; Fig. 2A). Seventeen cores (1 m depth) were collected along five transects on Pallu Island during 2002 and 2003 using a 10-cm diameter Eijkelkamp percussion corer (Eijkelkamp, Giesbeek, The Netherlands). Transect locations were chosen according to topography and geomorphological units in order to study both lateral and longitudinal characteristics and evolution of the island (Fig. 2A, B).

On each core, subsamples for laboratory analysis, corresponding to $10 \mathrm{~cm}$ slices increments, were described, collected and homogenized.

Grain size analyses were performed by sieving a $100 \mathrm{~g}$ aliquot (dry weight) during two phases: a first phase of wet-sieving to separate silt and clay fractions $(<50 \mu \mathrm{m})$ from the sand and gravel fractions $(>50 \mu \mathrm{m})$, a second phase of dry-sieving using standard methods (RoTap) to separate the following fractions: gravels ( $\mathrm{G},>\sim 2 \mathrm{~mm})$, coarse sands (CS, $500 \mu \mathrm{m}-2 \mathrm{~mm}$ ), medium sands (MS, 200-500 $\mu \mathrm{m}$ ), fine sands (FS, 50-200 $\mu \mathrm{m}$ ). Therefore, sandy and gravely fractions used for ${ }^{137} \mathrm{Cs}$ analysis did not present clay-silty coatings. Silt and clay fraction $(\mathrm{F}<50 \mu \mathrm{m})$ used for ${ }^{137} \mathrm{Cs}$ analysis is composed of clay and silt due to wetsieving added to clay and silt produced by attrition during sand and gravel dry-sieving. The grain size was analysed for all 10-cm increments composing cores Co4 to Co7. On the other thirteen cores, grain size analyses were conducted only on the increment corresponding to maximum ${ }^{137} \mathrm{Cs}$ activity.

\section{2. ${ }^{137}$ Cs method and analysis}

${ }^{137} \mathrm{Cs}$ is an anthropogenic radioactive fission product with a half-life of 30.17 years that was released into the atmosphere during nuclear weapons testing in the 1950s and 1960s (Cambray et al., 1989). Significant fallout of ${ }^{137}$ Cs started in 1954, peaked in 1959 and 1963 and declined to very low levels by about 1975 as a result of the 1963 Nuclear Test Ban Treaty (Walling and Bradley, 1990). An additional short-term input occurred in 1986, following the Chernobyl nuclear power plant disaster that released ${ }^{137}$ Cs into the troposphere (Cambray et al., 1987). Part of the radioactive plume moved south, west, and SW of Chernobyl, crossing Germany, Switzerland, Italy, France, and England amongst others (ApSimon and Wilson, 1986). As discussed by Cambray et al. (1987), atmospheric ${ }^{137} \mathrm{Cs}$ content in Europe remained at nearly 4 times peak 1963 levels for 2 to 3 months.

In most environments when ${ }^{137} \mathrm{Cs}$ reaches the earth surface with rainfall, it is rapidly and strongly fixed by clay particles, soil colloids and organic material ([Frissel and Penders, 1983], [Evans et al., 1983] and [Livens and Rimmer, 1988]). Subsequently, particles containing ${ }^{137} \mathrm{Cs}$ can migrate laterally by erosion and deposition processes and also vertically as a result of potential bioturbation (Steiger et al., 2001). Presence of ${ }^{137} \mathrm{Cs}$ in floodplain sediments results from two primary sources. The first corresponds to direct atmospheric fallout on the floodplain surface. The second source is catchment-derived, particle-associated radionuclides eroded in the catchment, subsequently mobilized by erosion, transported downstream, and deposited on the floodplain during overbank flooding (Walling et al., 1996). 
Two classic approaches were used in this study to characterize erosion/accretion areas and to determine sedimentation rates on Pallu Island. The first approach consisted in examining and comparing ${ }^{137} \mathrm{Cs}$ activity profiles, identifying the following two layers: maximum depth of

${ }^{137} \mathrm{Cs}$ penetration, assumed to correspond to the year 1954, and the 1963 peak corresponding to the period of maximum nuclear testing ([Ritchie et al., 1975] and [Walling and He, 1993]). The second approach involved measuring the total ${ }^{137} \mathrm{Cs}$ inventory in a profile and comparing it with the ${ }^{137} \mathrm{Cs}$ inventory at a reference site located in the vicinity ([Walling and He, 1994] and [Walling and He, 1997]). In this study, the total ${ }^{137} \mathrm{Cs}$ inventory was used as a tool to infer erosion/accretion areas by comparison with reference sites (undisturbed soils) corresponding to two private fallows disused from many decades, delimited by a boundary fence. These reference sites are located $25 \mathrm{~km}$ west of Bréhémont and display a mean value of $1570 \mathrm{~Bq}$ $\mathrm{m}^{-2}$ (corrected for year 2003 from Fourmont, 2001). This value is of the same order of magnitude as other reference sites in France or border countries (see Sogon, 1999, Table 23, p. 141).

Accretion rates $\left(S\right.$, mm year $^{-1}$, Table 1$)$ were calculated by using the depth of first appearance of ${ }^{137} \mathrm{Cs}$, corresponding to the year 1954 as follows:

\section{$\underline{S=Z / t}$}

where $Z(\mathrm{~mm})$ is the active depth corresponding to the first release of ${ }^{137} \mathrm{Cs}$ in 1954 (significant values $>\sim 1 \mathrm{~Bq} \mathrm{~kg}^{-1}$ ), and $t$ is the time between 1954 and the present study (49 years), as some of the profiles do not clearly show the 1963 peak. Even if the coarse grain size of the sediment allowed downward migration of the fine fraction, an increase in ${ }^{137} \mathrm{Cs}$ activity from base to top of cores was frequently observed in the profiles; this trend is assumed to represent the evolution of ${ }^{137} \mathrm{Cs}$ accumulation since 1954 for the estimation of sedimentation rates. However, when the first appearance of ${ }^{137} \mathrm{Cs}$ (1954) could not be clearly identified, the first appearance of ${ }^{137} \mathrm{Cs}$ may correspond to (1) post-1954 deposition as a result of erosion - possible in this episodically, highly dynamic environment — which could account for the absence of records for the first ${ }^{137} \mathrm{Cs}$ deposits or to (2) downward migration of fine ${ }^{137} \mathrm{Cs}$-charged particles toward the base of the profile. As a consequence, accretion rate values given in this work should be treated with caution as the rates are potentially balanced between minimum (case 1) and overestimated (case 2) values. Several models have been proposed to estimate floodplain sedimentation rates (e.g., [Walling and He, 1993], [Walling and He, 1997], [Goodbred and Kuehl, 1998] and [Stokes and Walling, 2003]). Major parametersincluding grain size, penetration depth of ${ }^{137} \mathrm{Cs}$, catchment-derived particle fluxes, and assumed constant sedimentation in the floodplain - are used to infer accurate sedimentation rates or spatial inventories. In the present work, calculating sedimentation rates using models could have led to unreliable results because of (i) the variability of sediment grain size, not only within a single core, but also between one core and another with a high sandy fraction and sometimes $<10 \%$ of clays; (ii) the variability of sedimentation rates during flooding events in an environment characterized by episodically highly dynamic water flows; (iii) the high sediment permeability, varying according to grain size, as a result of sandy fraction sediment contents that may allow downcore migration of fine particles containing ${ }^{137} \mathrm{Cs}$, leading to an overestimation of older sedimentation rates. 


\section{Results}

\subsection{Grain size of sediments}

Sediments on Pallu Island vary in grain size. Results of grain size analysis for cores Co4 to Co7 show various compositions for different increments in a single core; this grain size variability is also observed in other core sediments (Fig. 3). Gravels $(G)$ and coarse sands (CS) represent a small percentage of the total sediment composition in each core $(<2 \%$ for $G$ and $<11 \%$ for CS). Grain size is generally dominated by silt and clay (F) and fine sand (FS) fractions together with medium sands (MS), the latter accounting for up to $82 \%$ of the total sediment in Co5 increments. Grain size of the maximum ${ }^{137} \mathrm{Cs}$ activity increments in each core is relatively evenly distributed between MS, FS, and F fractions (Fig. 4A). This observation is corroborated by the low correlation coefficient $(0.53)$ calculated between the percentage of the $\mathrm{F}$ fraction and the specific activities of each highly active increment (Fig. 4B).

The specific activities of the main grain size class of the three increments (Co4 75-88, Co6 10-20, Co18 00-07) were investigated (Table 2). Samples were chosen on the basis of (i) grain sorting and (ii) high ${ }^{137} \mathrm{Cs}$ content. The activity of each class of sediment grain size shows that the whole sandy fraction can retain $\sim 20 \%$ of the ${ }^{137} \mathrm{Cs}$, with values decreasing from FS to CS (Table 2).

\subsection{Pallu Island morphology (Fig. 2)}

The northern bank of the island, along the main channel, presents the characteristics of a natural levee ([Reineck and Singh, 1980] and [Brierley et al., 1997]) intermittent in its upstream part with a relatively steep sandy bank sloping toward the inner part of the island with increasingly fine particle contents (unit a, Fig. 2B). Parallel to the Co1-Co15 segment and near Co10, the boundary between the island and the main channel is abrupt. The contact is smoother alongside the Co15-Co10 and Co10-Co14 segments. The median part of the island shows the highest topographic values with a ridge corresponding to the Co2-Co14 segment aligned parallel to the main channel and the secondary channel A (unit c). However, the SW-NE elongated area shows lower topographic values corresponding to a channel-like central depression along the Co1-Co10 segment (unit b). The boundary between Pallu Island and the secondary channel $\mathrm{A}$ is characterized by a gently sloping area corresponding to a channel shelf (as defined by Hupp, 1988) on which Co3, Co4, and Co12 cores are located (unit d).

\section{3. ${ }^{137} \mathrm{Cs}$ activity profiles and total inventory values}

Activity profiles exhibit three general patterns (Détriché, 2003) corresponding to different sediment-deposition dynamics (Fig. 3) as already observed by Walling and He (1993). Type I profiles are characterized by a linear to exponential decreasing trend of ${ }^{137} \mathrm{Cs}$ activities from the top to the base of the cores. The highest value of activity is observed in the uppermost layer. It decreases continuously downward, reaching near-zero values at depths of less than $40 \mathrm{~cm}$. It is observed in the central elevated part of the island (unit c) as well as in the central depression (unit b, Fig. 2 and Fig. 5). Close to the main channel banks (unit a), type II profiles show a subsurface peak and a progressive decrease of activity with increasing depth. The ${ }^{137} \mathrm{Cs}$ activity decreases toward the top of profile but it never reaches zero value. Along the channel shelf (unit d near secondary channel A), type III profiles show deep ${ }^{137}$ Cs penetration, 
sometimes extending to depths of more than $100 \mathrm{~cm}$ (Fig. 3 and Fig. 5). These profiles show two patterns, (i) one corresponding to high activity layers alternating irregularly with lower activity layers, and (ii) one showing high, nearly uniform activity throughout the profile. In the two cases, ${ }^{137} \mathrm{Cs}$ activity never decreases toward the profile bottom.

Total inventory values show strong variations from one core to another, varying from 458 to $8628 \mathrm{~Bq} \mathrm{~m}^{-2}$ (Table 1). Strong activities are observed in cores located along the channels (main and side branches, Fig. 5A). These cores correspond to type II-III profiles with high penetration depths of ${ }^{137} \mathrm{Cs}$ and fine fraction-rich sediments. Conversely, low values are observed in the median part of the island in cores characterized by low penetration depth of ${ }^{137}$ Cs corresponding to type I profiles (Fig. 5A).

\subsection{Sediment budgets and accretion rates}

By comparing the total ${ }^{137} \mathrm{Cs}$ activity inventory values to the reference site, sediment budget (erosion, stability, or accretion) corresponding to each sediment core was inferred (Table 1). Total inventories and sediment budgets are influenced by the environment evolution as the island is not a static body. Sediment budgets are viewed in relation with the different geomorphological units i.e. their present day dynamic and their past evolution inferred from observation of aerial photographs.

A relationship between sediment budget, profile shapes and geomorphological units can be determined. Generally, type I profiles correspond to erosion processes or stable conditions, while type II and III profiles are linked to accretion processes as shown by results of the ${ }^{137} \mathrm{Cs}$ inventory method (Tab. 1; Fig. 5C). Thus, the channel shelf along secondary channel A (unit d) and also the area behind the natural levee at the northern and the downstream ends of the island (unit a) are accreting (total inventory $\sim 1570 \mathrm{~Bq} \mathrm{~m}^{-2}$ ), while stability or erosion is occurring at both the centre and the upstream parts of the island (units b and c). More precisely, near-bank sediment cores display type II and type III profiles with high ${ }^{137} \mathrm{Cs}$ total inventory and penetration depth values characterizing accretion processes, while inland sediment cores display type I profiles with low total inventory and penetration depth values.

Accretion rates calculated with the penetration depth method (Walling and He, 1993) vary from 6.1 to $20.4 \mathrm{~mm}_{\text {year }}{ }^{-1}$ with high values $\left(>15 \mathrm{~mm}\right.$ year $\left.^{-1}\right)$ in the southern channel shelf and low values $\left(<10 \mathrm{~mm}\right.$ year $\left.^{-1}\right)$ in the northern area behind the natural levee (see Fig. 5A).

\section{Discussion}

\section{1. ${ }^{137}$ Cs retention by sandy sediments}

Variations in sediment grain size (and therefore mineralogy) and ${ }^{137} \mathrm{Cs}$ activities appear to be linked, but ${ }^{137} \mathrm{Cs}$ does not appear to be retained only by clay-sized particles, as shown in Fig. 4.

This characteristic is mainly observed in cores located in the median part of the island, characterized by type I-shaped ${ }^{137} \mathrm{Cs}$ activity profiles (Fig. 3). In these cores, sands constitute most of the sediment, even in high ${ }^{137} \mathrm{Cs}$-content layers. However, the increased ${ }^{137} \mathrm{Cs}$ activity observed in the upper part of the cores is paralleled by the increase in F and FS contents. This

${ }^{137} \mathrm{Cs}$ profile shape results from dominant erosion processes or stability. The associated relatively coarse grain size could be explained by (i) winnowing, or (ii) very low 
allochthonous sediment content and a resulting ${ }^{137} \mathrm{Cs}$ profile only from atmospheric input. In this case, ${ }^{137} \mathrm{Cs}$ activity appears to be linked mainly to atmospheric input and to the possible retention by sandy sediments.

Type II profiles are correlated with higher F and FS grain size contents that account for up to more than $70 \%$ of the sediment (Fig. 3). However, no correlation is observed between ${ }^{137} \mathrm{Cs}$ activity and grain size; more precisely, the grain size does not change when the ${ }^{137} \mathrm{Cs}$ content increases in the top part of the cores. In this case, ${ }^{137} \mathrm{Cs}$ activity seems to be linked mainly to atmospheric input and secondarily to sediment contribution.

Grain size correlated to type III profiles is dominated by FS and F particles, which can account for more than $60 \%$ of the total sediment. As type III profiles are characteristic of highly accreting zones, ${ }^{137} \mathrm{Cs}$ content could be partly linked to a high contribution of allochthonous, ${ }^{137}$ Cs-rich clays and silts as mentioned by Antonelli et al., 2008 on the Rhône River.

As shown in Table 2, sediment $\mathrm{S}$ fraction can retain ${ }^{137} \mathrm{Cs}$ (about 0 to $20 \%$ of total activity). The dominant sand-sized fraction in the Loire sediments consists mainly of quartz (about 65$70 \%$ ), but feldspars are very abundant (about 20\% alkali feldspars and 10\% plagioclases) with very low quantities of many other silicates such as micas and heavy minerals ([Macaire, 1981], [Brossé, 1982] and [Macaire, 1985]). The F fraction is mainly composed of silt grains with a similar composition to the sand, while clay minerals (mainly illite and kaolinite, traces of smectites, chlorite and interstratified minerals, [Macaire, 1981], [Brossé, 1982] and [Macaire, 1985]) are not abundant, especially in the studied area. Dion et al. (2005) assumed that ${ }^{137} \mathrm{Cs}$ in sandy sediments of the Savannah River was retained in certain specific sorption sites in mica present as coatings on sand-sized quartz particles. With regard to the ability of quartz and feldspars to retain radionuclides, De Meijer et al. (1990) showed that the specific activity of ${ }^{238} \mathrm{U}$ and ${ }^{232} \mathrm{Th}$ for quartz + feldspars is very low, namely $3 \mathrm{~Bq} \mathrm{~kg}^{-1}$. In a study of natural radionuclides in Loire sediments, Patryl (2000) found no significant correlation between the percentage of quartz and the activity of those radionuclides. Conversely, he observed that the activities of radionuclides in the uranium family (the most abundant) correlated with feldspar contents $\left(r^{2}\right.$ variable from 0.58 to 0.76$)$. As these elements cannot be included within the initial feldspar structure, Patryl (2000) concluded that they are absorbed from the water in clay minerals forming weathering features included in detrital feldspar grains, features that are frequently observed ([Macaire, 1981] and [Macaire, 1986]). In this way, ${ }^{137} \mathrm{Cs}$ in the sand-sized fraction of the Loire sediment could be retained mainly in feldspars.

\subsection{Sediment depositional dynamics from ${ }^{137} \mathrm{Cs}$ profiles}

Activity profiles from the Pallu Island sediments reflect different depositional dynamics showing typical patterns according to topography, distance from the surrounding channels, and vegetation density.

Total ${ }^{137} \mathrm{Cs}$ inventory value determined on each profile represents a sediment budget of the Loire system in each site from year 1954 or from a more recent year. This sediment budget can be of accretion, stability or erosion and can result from a complex evolution as shown by Walling and He (1993). 
Several interpretations can be proposed to explain the type I profile shape. (i) It can result from direct atmospheric ${ }^{137} \mathrm{Cs}$ inputs on alluvial surface which was stable or slightly eroded as shown by ${ }^{137} \mathrm{Cs}$ inventory values closed to the reference value or lower. The profile pattern could only indicate low penetration depth of ${ }^{137} \mathrm{Cs}$ (Goodbred and Kuehl, 1998). (ii) Type I profile can also be the result of sedimentary ${ }^{137} \mathrm{Cs}$ inputs during floods. In this case, low inventory values can be due to either high ${ }^{137} \mathrm{Cs}$ inputs during the period after 1954, then partly eroded as a consequence of increased water energy ([Goodbred and Kuehl, 1998] and [Steiger et al., 2001]), or to low ${ }^{137} \mathrm{Cs}$ inputs from 1954 or a more recent year. Nevertheless, even if allochthonous ${ }^{137} \mathrm{Cs}$ could be supplied by sediment deposition of catchment-derived particles, it appears to be diluted in the local atmospheric input record. Steady increase of ${ }^{137} \mathrm{Cs}$ activity toward the top of the profile in that fluvial context marked by irregular sedimentary processes and ${ }^{137} \mathrm{Cs}$ inventory values which are not higher than reference value indicated that hypothesis (i) is the most probable. Profile location shows that unit c (ridge) was eroded and unit b (channel-like depression) was mainly stable (Fig. 5C).

Type II profiles are similar to undisturbed profiles of sediments, inferring steady moderate accumulation during the last fifty years, such as floodplain deposits. In this case, ${ }^{137} \mathrm{Cs}$ comes mainly from atmospheric inputs ([Walling and He, 1993], [He et al., 1996], [Goodbred and Kuehl, 1998] and [Zhang and Walling, 2005]). ${ }^{137}$ Cs appearance at the bottom of profile corresponds approximately to the year 1954 and the peak value probably indicates the maximum atmospheric ${ }^{137} \mathrm{Cs}$ input at the year 1963 . Nevertheless, ${ }^{137} \mathrm{Cs}$ values which are not equal to zero at the top of profiles also testify of sedimentary inputs. Furthermore,

bioturbation inside the upper layers could lead to an incorporation of ${ }^{137} \mathrm{Cs}$ by mixing surface and underlying sediments (ancient pasture). Total inventory values and presence of atmospheric ${ }^{137} \mathrm{Cs}$ peak values in type II profiles indicate that sediment accretion on unit a (levee) and on the downstream part of unit b (Fig. 5C) have been moderate.

Irregular or nearly uniform and deep (more than $1 \mathrm{~m}$ in depth) ${ }^{137} \mathrm{Cs}$ distribution without 1964 peak appearance, and high inventory values in type III profiles, indicate rapid sediment accretion during floods (Walling and He, 1993). This pattern does not correspond to downward migration of ${ }^{137} \mathrm{Cs}$ as content does not decrease progressively toward the profile bottom. The high sediment accretion can be associated with (i) the frequent floods with irregular pulse and related allochthonous particle supply, (ii) the morphological configuration of the channel-island boundaries favouring or reducing sediment deposition, and (iii) the presence of woody vegetation causing high flow resistance and sediment trapping. Type III profiles are mainly located in unit d (channel shelf) which is frequently flooded $\left(Q>1500 \mathrm{~m}^{3}\right.$ $\mathrm{s}^{-1}$ at the Langeais gauging station) and where the presence of riparian trees acts as a fine particle trap favouring ${ }^{137} \mathrm{Cs}$ retention (He and Walling, 1996).

To summarize, type I profile ${ }^{137} \mathrm{Cs}$ is mainly of atmospheric origin with direct fallout, type II profile ${ }^{137} \mathrm{Cs}$ has a mixed origin: direct fallout from atmosphere and fluvial sedimentary inputs of allochthonous material, and type III profile ${ }^{137} \mathrm{Cs}$ is mainly of sedimentary origin.

\subsection{Sedimentological and geomorphological evolution of the island since 1954}

Four morphological units were identified on Pallu Island (Fig. 2B): a natural levee fringing the main channel (unit a), a central depression (unit b), a ridge (unit c), and a channel shelf (unit d) along the secondary channel A. Correlations between topographical and total ${ }^{137} \mathrm{Cs}$ 
inventory data (Fig. 5D) highlight sediment accretion on units a and d while erosion or stability occurs on units $b$ and $c$.

The levee (unit a) is accreting vertically. In the downstream part of this unit, sediments are characterized by high total ${ }^{137} \mathrm{Cs}$ inventory values, while accretion thickness is lower upstream: $0.28 \mathrm{~m}$ for $\mathrm{Co} 7$ and Co15. Near Co10, low ${ }^{137} \mathrm{Cs}$ activities show an erosion area, which corresponds to a break in the natural levee, directly linked to the central depression (unit b). Laterally, the levee is subject to severe ongoing erosion evidenced by the steepness of the bank and its significant slope toward the main channel (Fig. 6). The absence of riparian trees (Fig. 6A: 1) shows that this process was already active in the 1950s. The sediment budget in the levee area may be strongly negative from lateral scouring, although on the basis of ${ }^{137} \mathrm{Cs}$ data only it would appear to be accreting (Fig. 5C). The sediment deposition in this area occurs only during inundation of the island by large-magnitude floods that are rare, timelimited and characterized by small quantities of sediment deposited on this elevated surface. Conversely, lateral erosion occurs during almost all flood events, especially during the falling limb of the hydrograph when water is drained by the main channel. This phenomenon is visible on the adjacent upstream island (Fig. 6: 3).

The central depression (unit b) corresponds to an inland channel where winnowing occurs during large-magnitude floods. The first outlet of the depression is located near Co10 and the second near Co13. The sedimentation rate (Table 1) calculated for Co13 shows that roughly $0.65 \mathrm{~m}$ of sediment was deposited between 1954 and 2003. In this area, accretion can be assumed to be linked to the deposition of sediments scoured upstream (Co1, Co6, and Co16).

Based on the ${ }^{137} \mathrm{Cs}$ data, the median ridge (unit c), characterized by coarser sandy deposits, is an area of erosion or relative stability (Fig. 5C). This ridge is characterized by a relatively even morphology with a gentle slope toward the adjacent central depression. The wedgeshaped cross section, the predominance of medium-sized sands (Co5, Fig. 3) corresponding to the suspended load of the Loire during floods, and the presence of type I ${ }^{137} \mathrm{Cs}$ profiles are evidence of a former natural levee being vertically eroded during high-magnitude floods. The fact that no typical stratification of levee deposits was observed in cores could be explained by intense bioturbation on this former pastureland. Evidence for the abandonment of this levee also comes from the fining upward sequence that, in accordance with Bridge (2003), can be interpreted as one such depositional environment. This hypothesis implies that this levee was abandoned after the 1950s, probably because of the vertical incision of the main channel of the Loire. This phenomenon may have induced a decrease in the frequency and duration of flooding with a subsequent reduction in sediment supply from (i) a low number of high-magnitude floods, (ii) an increase in the relative height of this site, (iii) a reduced sediment supply of the secondary channel A which was gradually disconnected, and (iv) an intense sediment trapping in the channel shelf (unit d; Fig. 2B) resulting in a decrease in sediments available for deposition. During high-magnitude flood events $\left(Q>2300 \mathrm{~m}^{3} \mathrm{~s}^{-1}\right)$, this ridge (unit c) is fully submerged and eroded by axial flows (from Co1) subsequently drained to the main channel through the outlets of unit $b$.

The channel shelf along the secondary channel A (unit d; Fig. 2B) is clearly visible in the field below the slope break around the $\mathrm{Co} 4$ and Co12 cores (Fig. 2A). This unit is frequently flooded $\left(Q>1500 \mathrm{~m}^{3} \mathrm{~s}^{-1}\right.$ at the Langeais gauging station). Fine particles are deposited during high water periods because of flow resistance by riparian trees. As a result, accretion occurs (i) laterally southeastward with the development of the shelf ( $\sim 4$ m wide), and (ii) vertically with high accretion rates $\left(\sim 20 \mathrm{~mm}^{\text {year }}{ }^{-1}\right)$. These results are in line with those obtained from 
dendrogeomorphological analyses (Rodrigues, 2004). Based on ${ }^{137} \mathrm{Cs}$ data, roughly $0.72 \mathrm{~m}$ of sediments was deposited (Co3, Co4, and Co12) between 1954 and 2003 (Table 1).

To summarize, sedimentary and morphological evolutions of Pallu Island since 1950 are linked to the balance between longitudinal/lateral and vertical scour/fill processes acting during flood events and to the supply of sediment from channels splitting up around the island. As shown by Thorne et al. (1993) in another context, most of the morphological changes affect the margins of the island, while its centre is only affected by low vertical changes (only a few decimeters). The lateral SE migration of the island is reduced; while longitudinal erosion, corresponding to the frontal scouring of the bank, is significant (ca. $95 \mathrm{~m}$ ), leading to a substantial widening of the entrance to the secondary channel (Fig. 6:2).

This evolution of Pallu Island occurred while the bed of the Loire was adapting to the incision of its main channel, estimated to be $0.8 \mathrm{~m}$ at the Langeais gauging station ( $4.5 \mathrm{~km}$ upstream) between 1978 and 2002 (DIREN Centre data). The morphology of Pallu Island has been influenced by several factors: (i) a decrease in sediment supply deposited at the top of the island, (ii) strong lateral and frontal erosion assumed to be triggered by a change in flow direction during flood events since the 1950s, (iii) abandonment and erosion of the topmost layers corresponding to former levee deposits and to the central depression, (iv) significant sediment deposition on the lee side (Church and Jones, 1982), and (v) development of a channel shelf that corresponds to a new bank along the secondary channel. The southeastward migration is limited laterally by the presence of an incised part of the secondary channel downstream. The creation of the channel shelf could be interpreted as a response of the secondary channel A to the incision affecting the main channel. The induced narrowing effect (Osterkamp, 1998) is reinforced by the development of cross-sectional asymmetry triggered by in-channel woody vegetation colonization (Rodrigues et al., 2006). This phenomenon was observed for the other channels of the site, which have also become narrower since the $1950 \mathrm{~s}$ (Fig. 6: 4, 5, and 6).

\section{Conclusion}

The aim of this paper was to apply the ${ }^{137}$ Cs methodology to sandy sediments of the River Loire (France) to infer the morphological evolution of an alluvial island during the last 50 years, which corresponds to a period of incision of the river from human activities also noted on numerous European and North American fluvial systems ([Peiry, 1987], [Hupp and Simon, 1991], [Bravard et al., 1997], [Tockner et al., 2000] and [Arnaud-Fasseta, 2003]). Firstly, results provide evidence of ${ }^{137} \mathrm{Cs}$ retention by sandy particles, potentially in clay minerals forming weathering features included in detrital feldspar grains. However, these observations, corroborating those made by Dion et al. (2005) on the Savannah River, highlight the need to understand the mechanisms of the retention potential of ${ }^{137} \mathrm{Cs}$ by sand. Secondly, morphological changes of the island and sediment budgets were investigated. These are closely related to the particular relationships observed between topography, morphology, hydrology, grain size, and ${ }^{137} \mathrm{Cs}$ activity in sediments. Based on the ${ }^{137} \mathrm{Cs}$ inventory and activity profiles, low topographical areas near bank deposits are characterized by accreting processes, while the "inland" part of the island appears relatively stable or affected by reduced vertical erosion processes (as shown by Thorne et al., 1993). Sedimentary processes on the island represent an adjustment of the morphological configuration of the study site (Grivel, 2008) to the lowering of the main channel and to the associated decrease in flow capacity in the secondary branch. On Pallu Island, this adjustment develops to the detriment of the morphological configuration inherited from the "before incision times". In the downstream 
part of the island, sediment deposition prevails. On the margins of the island, processes differ according to the order of the channels - namely main and secondary branches. These processes induce the southwestward migration of the island. On one hand, a severe frontal and lateral scouring, not compensated by the formation of a natural levee during rare largeamplitude flood events, occurs at the boundary with the main channel. On the other hand, the abandonment and vertical erosion of a former levee at the top of the bank and very high sedimentation rates downslope enhance the development of a channel shelf at the edge of the secondary channel. Results given by the local investigations done on an island of the Loire can be transposed, to a certain extent, to several reaches of the river in its middle part and also to other multiple-channel rivers affected by incision.

This study shows that the ${ }^{137} \mathrm{Cs}$ method can be used to explain the vertical morphological evolution of islands in incised, sandy multiple-channel river systems affected by human activities. As this example illustrates, in order to be relevant, this type of method needs to be complemented by morphological and sedimentological analyses, taking into account lateral fluxes provided by the bordering channels.

\section{Acknowledgments}

This work was conducted in parallel with a study by S. Rodrigues, Ph.D. (Université François Rabelais, Tours, 2004) entitled "Dynamique sédimentaire et végétation : évolution de chenaux fluviatiles en Loire moyenne (France)".

The authors wish to thank C. Blanchard, M. Chassaing, A. Fourmont, A. Latapie, I. PeneGalland, N. Stienne, and J. Ursely for their field assistance. Laboratory assistance of A. Arous and M.-O. Sornein at the L.S.C.E. was greatly appreciated and helpful. We gratefully acknowledge two anonymous reviewers for their thoughtful and constructive reviews.

\section{References}

Allain-Jegou, 2002 Allain-Jegou, C., 2002. Relations végétation-écoulement-transport solide dans le lit des rivières. Etude de l'Isère dans le Grésivaudan., Ph.D. Thesis, INPG, Grenoble, France (in French).

Antonelli et al., 2008 C. Antonelli, F. Eyrolle, B. Rolland, M. Provansal and F. Sabatier, Suspended sediment and 137Cs fluxes during the exceptional December 2003 flood in the Rhone River, southeast France, Geomorphology 95 (2008), pp. 350-360.

ApSimon and Wilson, 1986 H. ApSimon and J. Wilson, Tracking the cloud from Chernobyl, New Scientist 1517 (1986), pp. 42-45.

Arnaud-Fasseta, 2003 G. Arnaud-Fasseta, River channel changes in the Rhone Delta (France) since the end of the Little Ice Age: geomorphological adjustment to hydroclimatic change and natural resource management, Catena 51 (2003), pp. 141-172.

Belleudy, 2000 P. Belleudy, Restoring flow capacity in the Loire river bed, Hydrological Processes 14 (2000), pp. 2331-2344.

Bravard et al., 1997 J.P. Bravard, C. Amoros, G. Pautou, G. Bornette, M. Bournaud, M. Creuzé des Châtelliers, J. Gibert, J.L. Peiry, J.F. Perrin and H. Tachet, River incision in south- 
east France: morphological phenomena and ecological effects, Regulated Rivers: Research and Management 13 (1997), pp. 75-90.

Bridge, 2003 J.S. Bridge, Rivers and Floodplains, Forms, Blackwell Publishing, Oxford, UK, Processes and Sedimentary Record (2003).

Brierley et al., 1997 G.J. Brierley, R.J. Ferguson and K.J. Woolfe, What is a fluvial levee?, Sedimentary Geology 114 (1997), pp. 1-9.

Brossé, 1982 Brossé, R., 1982. Les processus sédimentaires dans le fleuve Loire. Ph.D. Thesis, Université d'Angers, France (in French).

Burnouf, 2001 J. Burnouf, Les concepts de "crise" et de "stabilite" : la notion de "risques", Projet CNRS-PEVS Interactions Homme-Milieu dans le bassin versant de la Loire, France (2001) (in French).

Cambray et al., 1987 R.S. Cambray, P.A. Cawse, J.A. Garland, J.A.B. Gibson, P. Johnson, G.N.J. Lewis, D. Newton, L. Salmon and B.O. Wade, Observations on radioactivity from the Chernobyl accident, Nuclear Energy 26 (1987), pp. 77-101.

Cambray et al., 1989 R.S. Cambray, K. Playford and R.C. Carpenter, Radioactive fallout in air and rain: results to the end of 1988, AERE-R-13575, UK Atomic Energy Authority Report, Harwell, UK (1989).

Campbell et al., 1982 B.L. Campbell, R.J. Loughran and G.L. Elliot, Caesium-137 as an indicator of geomorphic processes in a drainage basin system, Australian Geographical Studies 20 (1982), pp. 49-64.

Church and Jones, 1982 M. Church and D. Jones, Channel bars in gravel-bed rivers. In: R.D. Hey, J.C. Bathurst and C.R. Thorne, Editors, Gravel Bed Rivers, Wiley, Chichester (1982), pp. 291-324.

Cornier, 2002 Cornier, T., 2002. La végétation alluviale de la Loire entre le Charolais et l'Anjou : essai de modélisation de l'hydrosystème. Ph.D. Thesis, Université François Rabelais, Tours, France (in French).

Dacharry, 1974 Dacharry, M., 1974. Hydrologie de la Loire en amont de Gien, Paris, N.E.L., 2 volumes (in French).

Dambre and Malaval, 1993 J.L. Dambre and P. Malaval, Evaluation des conditions de poursuite de la politique de limitation des extractions de matériaux dans le Lit de la Loire du Bec d'Allier à Nantes, Mission d'inspection des services de la navigation - Mission d'inspection spécialisée de l'environnement, Paris, France (1993) (in French).

De Meijer et al., 1990 R.J. De Meijer, H.M.E. Lesser, R.D. Schuiling and M.E. Elburg, Estimate of the heavy mineral content in sand and its provenance by radiometric methods, Nuclear Geophysics 4 (1990), pp. 455-460. 
Détriché, 2003 Détriché, S., 2003. Application de la méthode du ${ }^{137}$ Cs à l'étude de la dynamique récente de la Loire (site de Bréhémont, Indre-et-Loire). Mémoire de DEA, Université de Tours, France (in French).

Dion, 1961 R. Dion, Histoire des levées de la Loire, Paris (1961) (in French).

Dion et al., 2005 H.M. Dion, C.S. Romanek, T.G. Hinton and P.M. Bertsch, Cesium-137 in floodplain sediments of the Lower Three Runs Creek on the DOE Savannah River site, Journal of Radioanalytical and Nuclear Chemistry 264 (2005), pp. 481-488.

Duband, 1996 D. Duband, La genèse des crues dans le bassin de la Loire, Houille Blanche 6 (1996), pp. 54-62.

Evans et al., 1983 D.W. Evans, J.J. Alberts and R.A. Clark III, Reversible ion-exchange fixation of Cesium-137 leading to mobilization from reservoir sediments, Geochimica et Cosmochimica Acta 47 (1983), pp. 1041-1049.

Fourmont, 2001 Fourmont, A., 2001. Analyse de l'évolution subactuelle des banquettes colluviales anthropiques par la méthode du Cs-137. Influence sur le bilan sédimentaire du bassin du Quincampoix (Sud-Ouest du Bassin Parisien). Mémoire de DEA, Université de Tours, France (in French).

Frissel and Penders, 1983 M.J. Frissel and R. Penders, Models for the accumulation and migration of ${ }^{90} \mathrm{Sr},{ }^{137} \mathrm{Cs},{ }^{239,}{ }^{240} \mathrm{Pu}$ and ${ }^{241} \mathrm{Am}$ in the upper layers of soils. In: P.J. Coughtrey, Editor, Ecological Aspects of Radionuclide Release, Blackwell, Oxford, UK (1983), pp. 6372 .

Gautier et al., 2005 E. Gautier, S. Grivel and D. Brunstein, The Loire River: the fluvial response to the coupled effects of hydrologic and socio-economic changes, Geophysical Research Abstracts 7 (2005), p. 03661.

Goodbred and Kuehl, 1998 S.L. Goodbred Jr. and S.A. Kuehl, Floodplain processes in the Bengal Basin and the storage of Ganges-Brahmaputra river sediment: an accretion study using ${ }^{137} \mathrm{Cs}$ and ${ }^{210} \mathrm{~Pb}$ geochronology, Sedimentary Geology 121 (1998), pp. 239-258

Gottesfeld and Johnson-Gottesfeld, 1990 A.S. Gottesfeld and L. Johnson-Gottesfeld, Floodplain dynamics of a wandering river, dendrochronology of the Morice River, British Columbia, Canada, Geomorphology 3 (1990), pp. 159-179.

Grivel, 2008 Grivel, S., 2008. La Loire des îles, du bec d'Allier à Gien : rythme d'évolution et enjeux de gestion. Ph.D. Thesis, Université Paris VIII, France (in French).

Gurnell and Petts, 2002 A.M. Gurnell and G.E. Petts, Island-dominated landscapes of large floodplain rivers, a European perspective, Freshwater Biology 47 (2002), pp. 581-600.

Gurnell et al., 2001 A.M. Gurnell, G.E. Petts, D.M. Hannah, B.P.G. Smith, P.J. Edwards, J. Kollmann, J.V. Ward and K. Tockner, Riparian vegetation and island formation along the gravel-bed Fiume Tagliamento, Italy, Earth Surface Processes and Landforms 26 (2001), pp. $31-62$. 
Hasholt and Walling, 1992 B. Hasholt and H.E. Walling, Use of caesium-137 to investigate sediment sources and sediment delivery in a small glacierized mountain drainage basin in eastern Greenland, International Association of Hydrological Sciences Publication, Erosion, Debris Flows and Environment in Mountain Regions, Proceedings of the Chengdu Symposium, July 1992. IAHS Publ. 209, Wallingford, UK 87-100 (1992).

He and Walling, 1996 Q. He and D.E. Walling, Rates of overbank sedimentation on the floodplains of British lowland rivers documented using fallout ${ }^{137} \mathrm{Cs}$, Geografiska Annaler. Series A. Physical Geography 78 (4) (1996), pp. 223-234.

He et al., 1996 Q. He, D.E. Walling and P.N. Owens, Interpreting the ${ }^{137}$ Cs profiles observed in several small lakes and reservoirs in southern England, Chemical Geology 129 (1996), pp. $115-131$.

Hupp, 1988 C.R. Hupp, Plant ecological aspects of flood geomorphology and paleoflood history. In: V.R. Baker, R.C. Kochel and P.C. Patton, Editors, Flood Geomorphology, Wiley, New York (1988), pp. 335-356.

Hupp and Simon, 1991 C.R. Hupp and A. Simon, Bank accretion and the development of vegetated depositional surfaces along modified alluvial channels, Geomorphology 4 (1991), pp. 111-124.

Kollmann et al., 1999 J. Kollmann, M. Vieli, P.J. Edwards, K. Tockner and J.V. Ward, Interactions between vegetation development and island formation in the Alpine river Tagliamento, Applied Vegetation Science 2 (1999), pp. 25-36.

Leopold and Wolman, 1957 L.B. Leopold and M.G. Wolman, River channel patterns: braided, meandering and straight, U.S. Geological Survey Professional Paper 282-B (1957), pp. 39-85.

Livens and Rimmer, 1988 F.R. Livens and D.L. Rimmer, Physico-chemical controls on artificial radionuclides in soils, Soil Use and Management 4 (1988), pp. 63-69.

Macaire, 1981 Macaire, J.-J., 1981. Contribution à l'étude géologique et paléopédologique du Quaternaire dans le Sud-Ouest du bassin de Paris (Touraine et ses abords). Ph.D. Thesis, Université François Rabelais, Tours, France (in French).

Macaire, 1985 J.-J. Macaire, Relations entre les altérites formées sur les roches endogènes du Massif central français et les épandages détritiques périphériques, au Cénozoïque récent, Géologie de la France 2 (1985), pp. 201-212.

Macaire, 1986 J.-J. Macaire, Sequence of polycyclic soils on plio-Quaternary alluvial deposits in south-western Paris basin (France): paleoecological significance, Catena 13 (1986), pp. $29-46$.

McHenry et al., 1976 J.R. McHenry, J.C. Ritchie and J. Verdon, Sedimentation rates in the Upper Mississippi River, Rivers '76, Symposium on Inland Waterways for Navigation, Flood Control and Water Diversions vol. II, American Society of Civil Engineers, Fort Collins, Colorado (1976), pp. 1339-1349. 
Nakayama et al., 2002 K. Nakayama, C.R. Fielding and J. Alexander, Variations in character and preservation potential of vegetation-induced obstacle marks in the variable discharge Burdekin River of North Queensland, Australia, Sedimentary Geology 149 (2002), pp. 199218.

Nanson and Croke, 1992 G.C. Nanson and J.C. Croke, A genetic classification of floodplains, Geomorphology 4 (1992), pp. 459-486.

Nanson and Knighton, 1996 G.C. Nanson and A.D. Knighton, Anabranching rivers: their cause, character and classification, Earth Surface Processes and Landforms 21 (1996), pp. 217-239.

Osterkamp, 1998 W.R. Osterkamp, Processes of fluvial island formation, with examples from Plum Creek, Colorado and Snake River, Idaho, Wetlands 18 (1998), pp. 530-545.

Patryl, 2000 Patryl, L., 2000. La radioactivité naturelle des sédiments de la Loire. Relations avec la lithologie. Ph.D. Thesis, Université François Rabelais, Tours, France (in French).

Peiry, 1987 J.L. Peiry, Channel degradation in the middle Arve River, France, Regulated Rivers: Research \& Management 1 (1987), pp. 183-188.

Peiry et al., 1994 J.-L. Peiry, P.-G. Salvador and F. Nouguier, L'incision des rivières dans les Alpes du nord : état de la question, Revue de Géographie de Lyon 69 (1994), pp. 47-56.

Petts et al., 1989 In: G.E. Petts, H. Möller and A.L. Roux, Editors, Historical Changes of Large Alluvial Rivers: Western Europe, Wiley, Chichester, UK (1989).

Piégay et al., 2000 H. Piégay, G. Bornette, A. Citerrio, E. Hérouin, B. Moulin and C. Statiotis, Channel instability as a control on silting dynamics and vegetation patterns within perifluvial aquatic zones, Hydrological Processes 14 (2000), pp. 3011-3029.

Reineck and Singh, 1980 H.E. Reineck and I.B. Singh, Depositional Sedimentary Environments, Springer-Verlag, Berlin (1980).

Ritchie et al., 1975 J.C. Ritchie, P.H. Hawks and J.R. McHenry, Deposition rates in valleys determined using fallout cesium-137, Geological Society of America Bulletin 86 (1975), pp. $1128-1130$.

Rodrigues, 2004 Rodrigues, S., 2004. Dynamique sédimentaire et végétation : évolution de chenaux fluviatiles en Loire moyenne (France). Ph.D. Thesis, Université François Rabelais, Tours, France (in French).

Rodrigues et al., 2006 S. Rodrigues, J.G. Bréhéret, J.J. Macaire, F. Moatar, D. Nistoran and P. Jugé, Flow and sediment dynamics in the vegetated secondary channels of an anabranching river: the Loire River (France), Sedimentary Geology 186 (2006), pp. 89-109.

Rodrigues et al., 2007 S. Rodrigues, J.G. Bréhéret, J.J. Macaire, S. Greulich and M. Villard, In-channel woody vegetation controls on sedimentary processes and the sedimentary record within alluvial environments: a modern example of an anabranch of the River Loire (France), Sedimentology 54 (2007), pp. 223-242. 
Sigafoos, 1964 R. Sigafoos, Botanical evidence of floods and flood-plain deposition, US Geological Survey Professional Paper 485-A (1964).

Sogon, 1999 Sogon, S., 1999. Erosion des sols cultivés et transport des matières en suspension dans un bassin versant de Brie. Application des traceurs naturels et radioactifs. Ph.D. Thesis, Université Paris I, Paris, France (in French).

Soster et al., 2007 F.M. Soster, G. Matisoff, P.J. Whiting, W. Fornes, M. Ketterer and S. Szechenyi, Floodplain sedimentation rates in an alpine watershed determined by radionuclide techniques, Earth Surface Processes and Landforms 32 (2007), pp. 2038-2051.

Steiger et al., 2001 J. Steiger, A.M. Gurnell, P. Ergenzinger and D. Snelder, Sedimentation in the riparian zone of an incising river, Earth Surface Processes and Landforms 26 (2001), pp. 91-108.

Stokes and Walling, 2003 S. Stokes and D.E. Walling, Radiogenic and isotopic methods for the direct dating of fluvial sediments. In: M. Kondolf and H. Piegay, Editors, Tools in Fluvial Geomorphology, Wiley, Chichester, UK (2003), pp. 233-267.

Terry et al., 2002 J.P. Terry, S. Garimella and R.A. Kostaschuk, Rates of floodplain accretion in a tropical island river system impacted by cyclones and large floods, Geomorphology $\mathbf{4 2}$ (2002), pp. 171-182.

Terry et al., 2006 J.P. Terry, R.A. Kostaschuk and S. Garimella, Sediment deposition rate in the Falefa River basin, Upolu Island, Samoa, Journal of Environmental Radioactivity 86 (2006), pp. 45-63.

Thorndycraft et al., 2005 V.R. Thorndycraft, G. Benito, D.E. Walling, A. Sopena, Y. Sánchez-Moya, M. Rico and A. Casas, Caesium-137 dating applied to slackwater flood deposits of the Llobregat River, NE Spain, Catena 59 (2005), pp. 305-318.

Thorne et al., 1993 C.R. Thorne, A.P.G. Russell and M.K. Alam, Planform pattern and channel evolution of the Brahmaputra River, Bangladesh. In: J.L. Best and C.S. Bristow, Editors, Braided Rivers, Geologic Society of America Special Publication vol. 75 (1993), pp. 257-276 London, UK.

Tockner et al., 2000 K. Tockner, C. Baumgartner, F. Schiemer and J.V. Ward, Biodiversity of a Danubian floodplain: structural, functional and compositional aspects. In: B. Gopal, W.J. Junk and J.A. Davis, Editors, Biodiversity in Wetlands: Assessment, Function and Conservation, Backhuys Publishers, Leiden, The Netherlands (2000), pp. 141-159.

Tooth and McCarthy, 2004 S. Tooth and T.S. McCarthy, Anabranching in mixed bedrockalluvial rivers: the example of the Orange River above Augrabies Falls, northern Cape Province, South Africa, Geomorphology 57 (2004), pp. 235-262.

Vautier et al., 2002 F. Vautier, J.-L. Peiry and J. Girel, Développement végétal dans le lit endigué de l'Isère en amont de Grenoble : du diagnostic à l'évaluation des pratiques de gestion, Revue d'Ecologie Terre et Vie, Supplément 9 (2002), pp. 65-79. 
Walling and Bradley, 1989 D.E. Walling and S.B. Bradley, Rates and patterns of contemporary floodplain sedimentation: a case study of the River Culm, Devon, UK, GeoJournal 19 (1989), pp. 53-62.

Walling and Bradley, 1990 D.E. Walling and S.B. Bradley, Some applications of Caesium137 measurements to the study of erosion, transport and deposition. In: D.E. Walling, A. Yair and S. Berkowicz, Editors, Erosion, Transport and Deposition Processes, Proceedings of the Jerusalem Workshop, IAHS Publ. vol. 189 (1990), pp. 179-203.

Walling and He, 1992 D.E. Walling and Q. He, Interpretation of caesium-137 profiles in lacustrine and other sediments: the role of catchment-derived inputs, Hydrobiologia 235 (236) (1992), pp. 219-230.

Walling and He, 1993 D.E. Walling and Q. He, Use of cesium-137 as a tracer in the study of rates and patterns of floodplain sedimentation. In: N.E. Peters, E. Hoehn, C.H. Leibundgut, N. Tase and D.E. Walling, Editors, Tracers in Hydrology, Proceedings of the Yokohama Symposium, July 1993, IAHS Publ. No. 215 (1993), pp. 319-328.

Walling and He, 1994 D.E. Walling and Q. He, Rates of overbank sedimentation on the flood plains of several British rivers during the past 100 years. In: L.J. Olive, R.J. Loughran and J.A. Kesby, Editors, Variability in Stream Erosion and Sediment Transport, Proceedings of the Canberra Symposium, December 1994, IAHS Publ. No. 224, Wallingford, UK (1994), pp. 203-210.

Walling and He, 1997 D.E. Walling and Q. He, Use of fallout ${ }^{137} \mathrm{Cs}$ in investigations of overbank sediment deposition on river floodplains, Catena 29 (1997), pp. 263-282.

Walling et al., 1996 D.E. Walling, Q. He and A.P. Nicholas, Floodplains as suspended sediment sinks. In: M. Anderson, D.E. Walling and P. Bates, Editors, Floodplain Processes, Wiley, Chichester, UK (1996), pp. 399-440.

Ward et al., 1999 J.V. Ward, K. Tockner, P.J. Edwards, J. Kollmann, G. Bretschko, A.M. Gurnell, G.E. Petts and B. Rossaro, A reference river system for the Alps: the Fiume Tagliamento, Regulated Rivers 15 (1999), pp. 63-75.

Wende and Nanson, 1998 R. Wende and G.S. Nanson, Anabranching rivers: ridge form alluvial channels in tropical northern Australia, Geomorphology 22 (1998), pp. 205-224.

Zhang and Walling, 2005 X. Zhang and D.E. Walling, Characterizing land surface erosion from Cesium-137 profiles in lake and reservoir sediments, Journal of Environmental Quality 34 (2005), pp. 514-523 


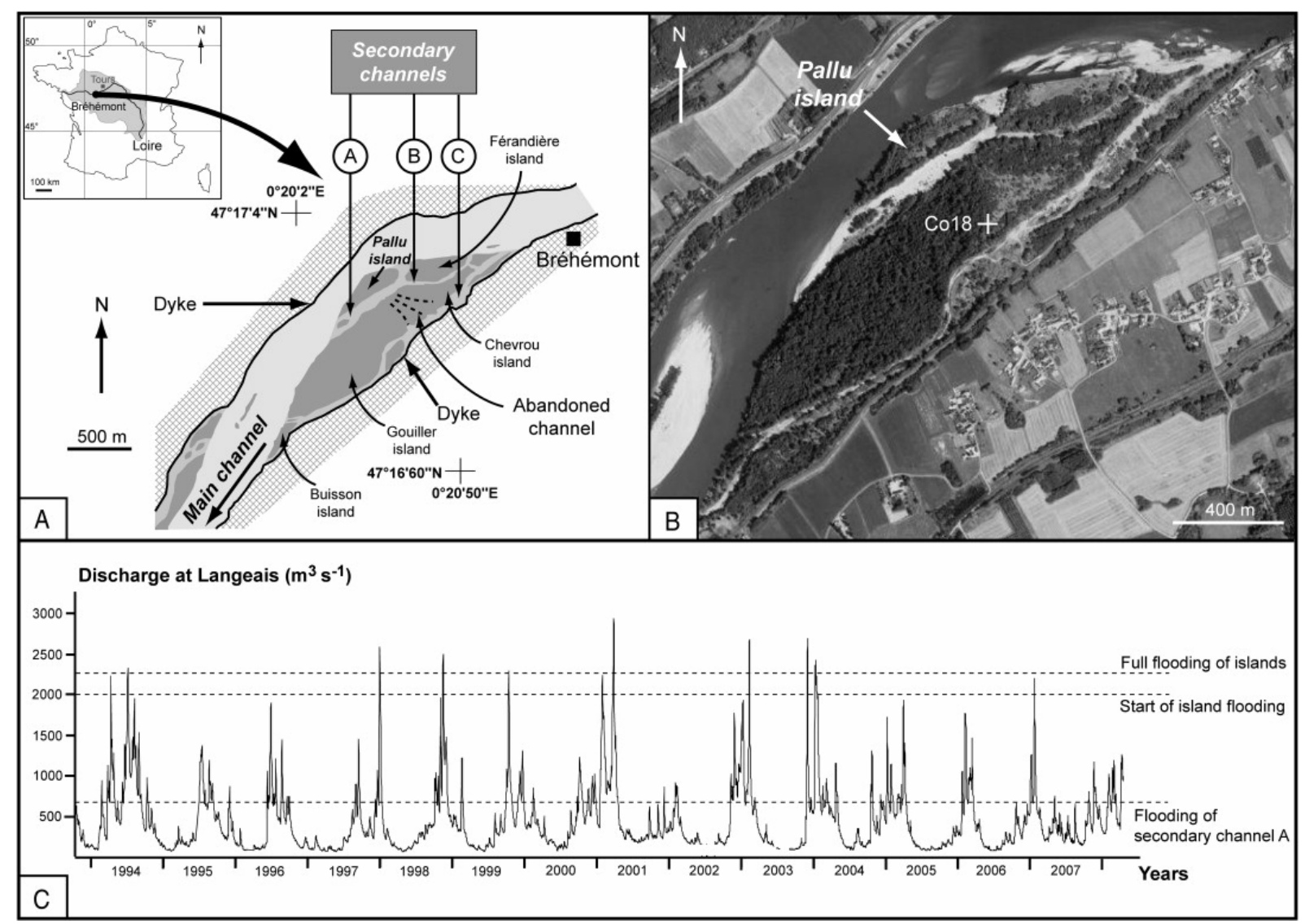

Fig. 1. Hydrological and morphological characteristics of the River Loire at the Bréhémont site. A-Location of the Bréhémont site and of Pallu Island in the Loire River basin. BAerial photograph of the study site (source: IGN, 2003) and location of Co18 core (see Table 2). C-Hydrograph at the Langeais gauging station (located $4.5 \mathrm{~km}$ upstream of the study site) between 1994 and 2008 (data from Diren Centre). 


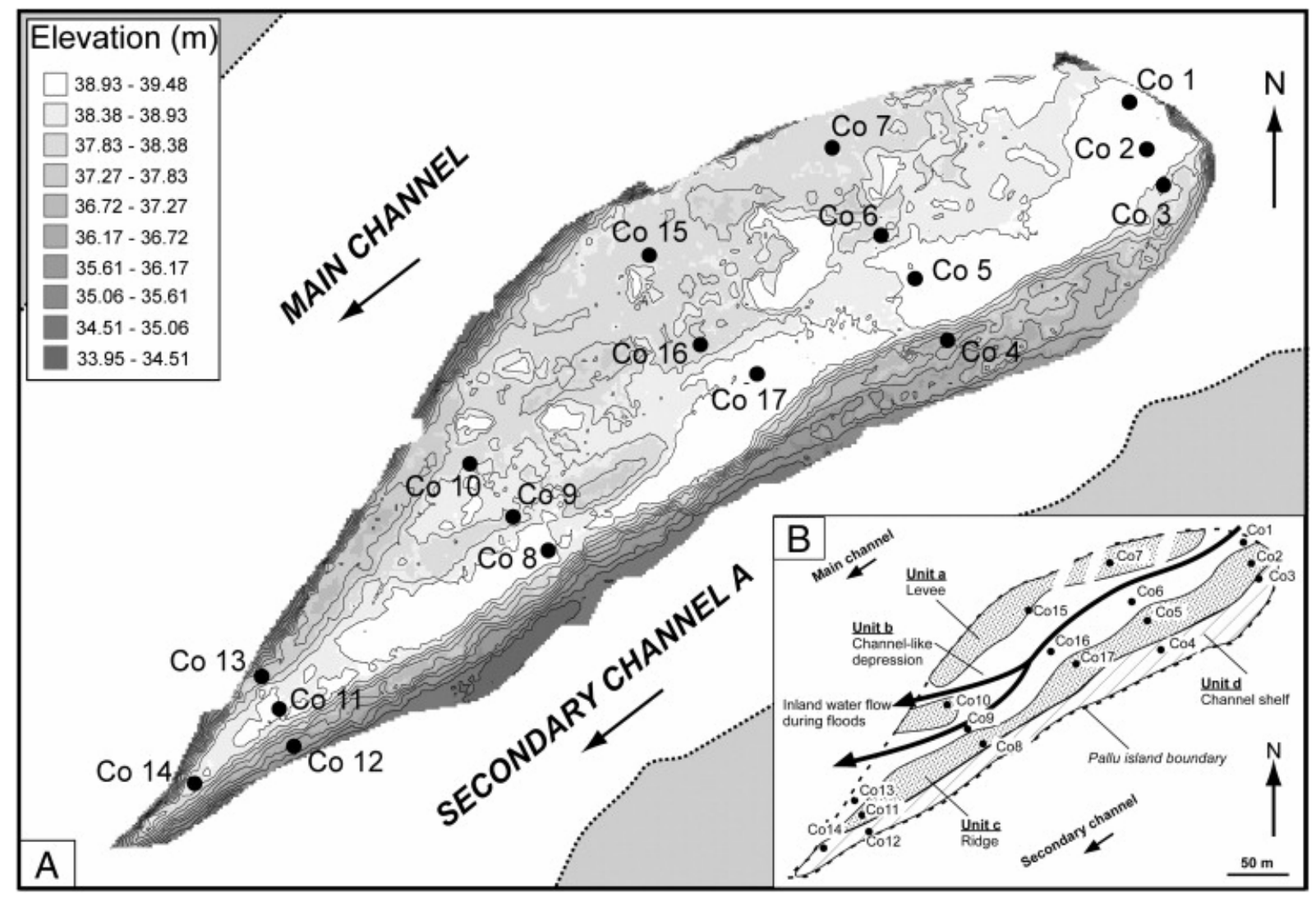

Fig. 2. Physical and morphological characteristics of Pallu Island and location of cores Co1 to Co17. A-Topographic map (surveys and LiDAR data). B-Repartition of the different morphological units of Pallu Island. 


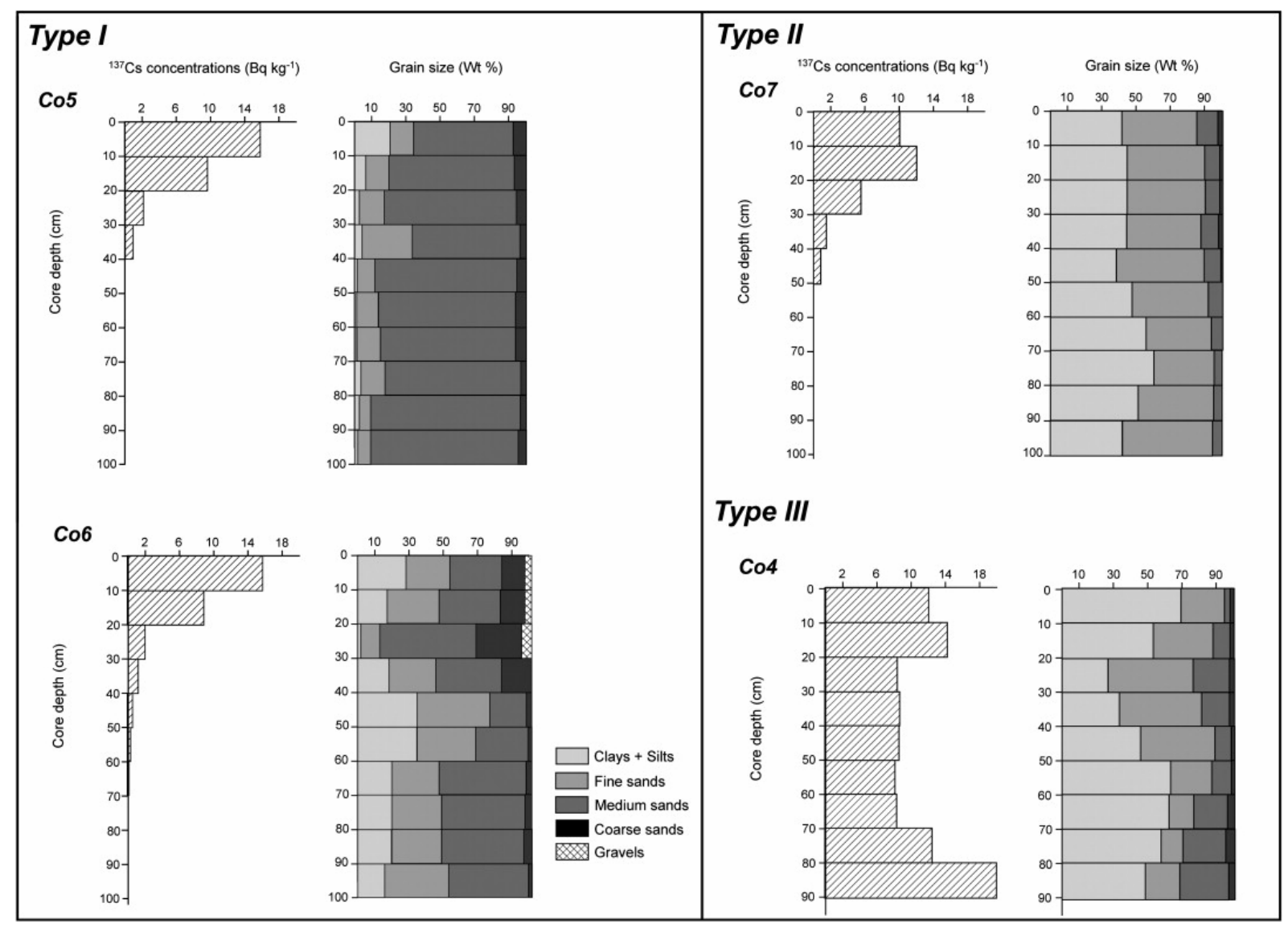

Fig. $3 .{ }^{137} \mathrm{Cs}$ activity profiles of four cores ( $\mathrm{Co} 4$ to $\left.\mathrm{Co} 7\right)$ showing three shapes and associated grain size. Activity errors are $<0.5 \mathrm{~Bq} \mathrm{~kg}^{-1}$. Core location is shown in Fig. 2.

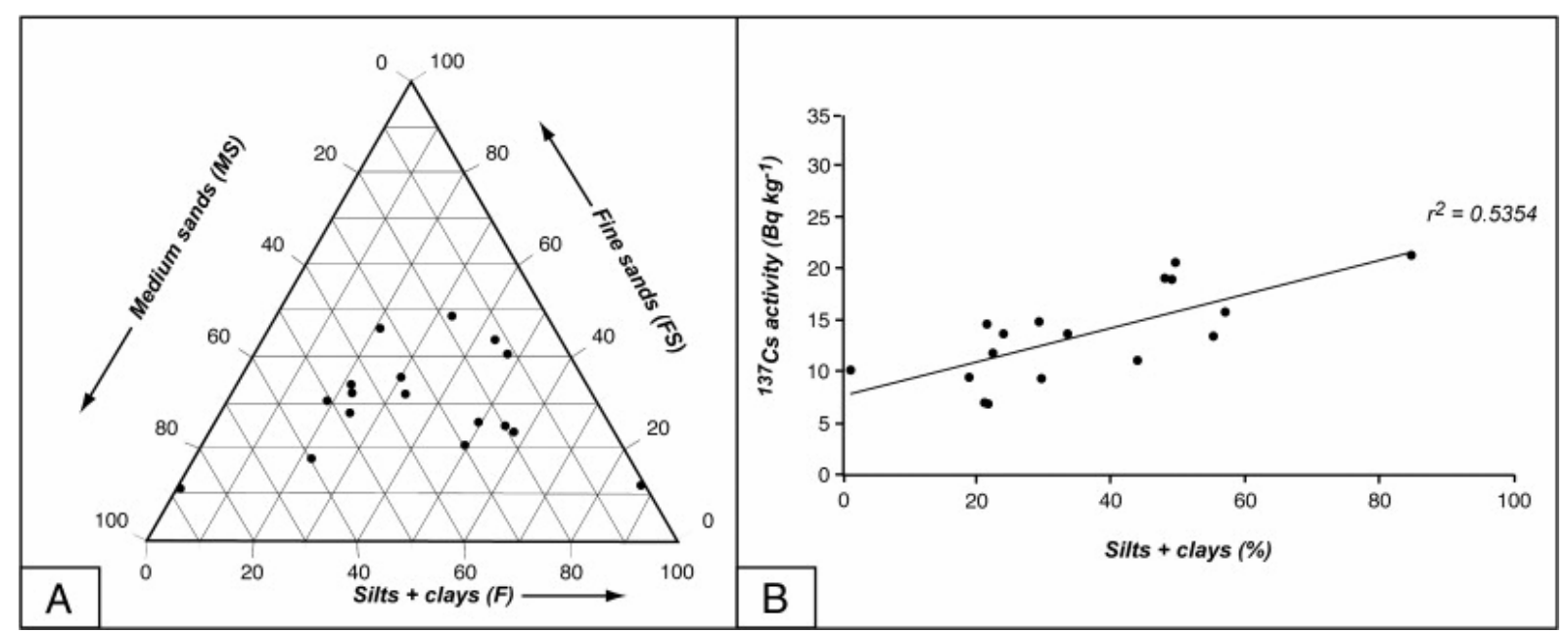

Fig. 4. Sediment grain size and ${ }^{137} \mathrm{Cs}$ activity data. A-Grain size of the maximum ${ }^{137} \mathrm{Cs}$ activity increment of each core (Co1 to $\mathrm{Co} 17)$. B - Correlation between percentage of the $\mathrm{F}$ fraction and specific activities of highly active increment in each core (Co1 to Co17). 


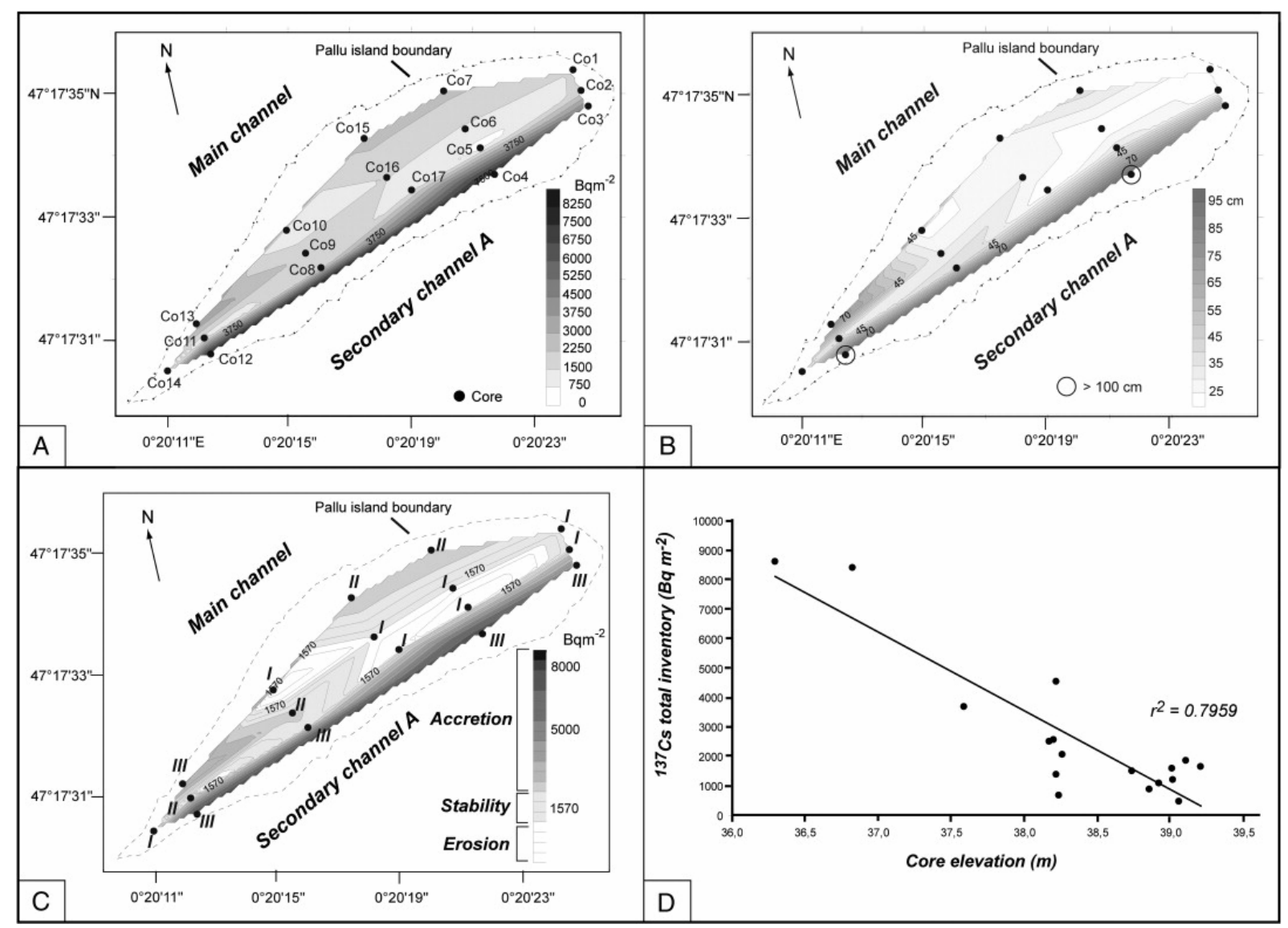

Fig. 5. Linear interpolation of ${ }^{137} \mathrm{Cs}$ distribution over Pallu Island. A-Total ${ }^{137} \mathrm{Cs}$ inventory. $\mathrm{B}-{ }^{137} \mathrm{Cs}$ penetration depth. $\mathrm{C}-$ Sediment budget inferred from total ${ }^{137} \mathrm{Cs}$ inventory and indication of ${ }^{137} \mathrm{Cs}$ profile types I to III. D- ${ }^{137} \mathrm{Cs}$ total inventory vs. core elevations. 


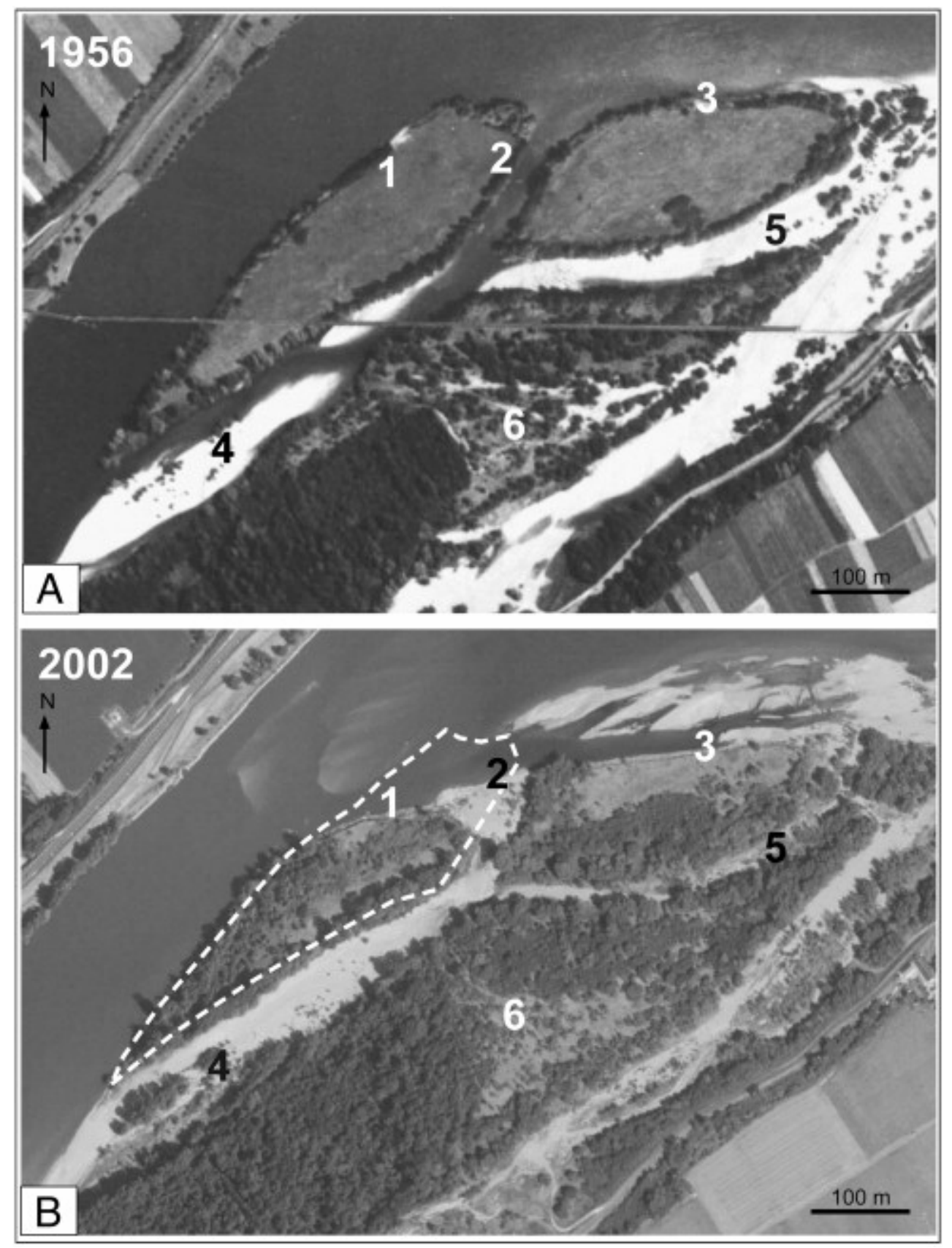

Fig. 6. Aerial photographs of the Bréhémont site in 1956 (A) and 2002 (B). The dashed line represents the shape of Pallu Island in 1956. See text for numbers. Photographs courtesy of the Direction Régionale de l'Environnement Centre. 

Table 1.

Core location, elevation and corresponding ${ }^{137} \mathrm{Cs}$ inventory, penetration depth, and profile type; inventory method results (using the reference value) and accretion rates.

\begin{tabular}{|c|c|c|c|c|c|c|c|}
\hline $\begin{array}{l}\text { Core } \\
\text { name }\end{array}$ & WGS84 location & $\begin{array}{l}\text { Elevation } \\
\text { (m) }\end{array}$ & $\begin{array}{l}{ }^{137} \mathrm{Cs} \text { inventory } \\
\left(\mathrm{Bq} \mathrm{m}^{-2}\right)\end{array}$ & $\begin{array}{l}\text { Max. depth of } \\
{ }^{137} \text { Cs activity } \\
\text { (cm) }\end{array}$ & $\begin{array}{l}{ }^{137} \mathrm{Cs} \\
\text { profile } \\
\text { type }\end{array}$ & $\begin{array}{l}\text { Erosion/accretion } \\
\text { (inventory method) }\end{array}$ & $\begin{array}{l}\text { Accretion rate } S \\
\left(\mathrm{~mm}_{\text {year }}{ }^{-1}\right)\end{array}$ \\
\hline $\mathrm{Co} 1$ & $\begin{array}{l}0^{\circ} 20^{\prime} 27.21^{\prime \prime} \mathrm{E}- \\
47^{\circ} 17^{\prime} 36.22^{\prime \prime} \mathrm{N}\end{array}$ & 39.01 & 1640 & 20 & $\mathrm{I}$ & Stable & - \\
\hline $\mathrm{Co} 2$ & $\begin{array}{l}0^{\circ} 20^{\prime} 27.52^{\prime \prime} \mathrm{E}- \\
47^{\circ} 17^{\prime} 35.67^{\prime \prime} \mathrm{N}\end{array}$ & 39.21 & 1662 & 22 & I & Stable & - \\
\hline $\mathrm{Co} 4$ & $\begin{array}{l}0^{\circ} 20^{\prime} 24.27^{\prime \prime} \mathrm{E}- \\
47^{\circ} 17^{\prime} 33.41^{\prime \prime} \mathrm{N}\end{array}$ & 36.83 & 8394 & $>100(1954)$ & III & Accretion & 20.4 \\
\hline Co5 & $\begin{array}{l}0^{\circ} 20^{\prime} 23.67^{\prime \prime} \mathrm{E}- \\
47^{\circ} 17^{\prime} 34.08^{\prime \prime} \mathrm{N}\end{array}$ & 39.06 & 458 & 33 & I & Erosion & - \\
\hline $\mathrm{Co} 8$ & $\begin{array}{l}0^{\circ} 20^{\prime} 17.65^{\prime \prime} \mathrm{E}- \\
47^{\circ} 17^{\prime} 30.85^{\prime \prime} \mathrm{N}\end{array}$ & 39.11 & 1907 & 40 & III & Accretion & 8.2 \\
\hline $\mathrm{Co} 9$ & $0^{\circ} 20^{\prime} 17.02^{\prime \prime} \mathrm{E}-$ & 38.26 & 2121 & 30 & II & Accretion & 6.1 \\
\hline
\end{tabular}




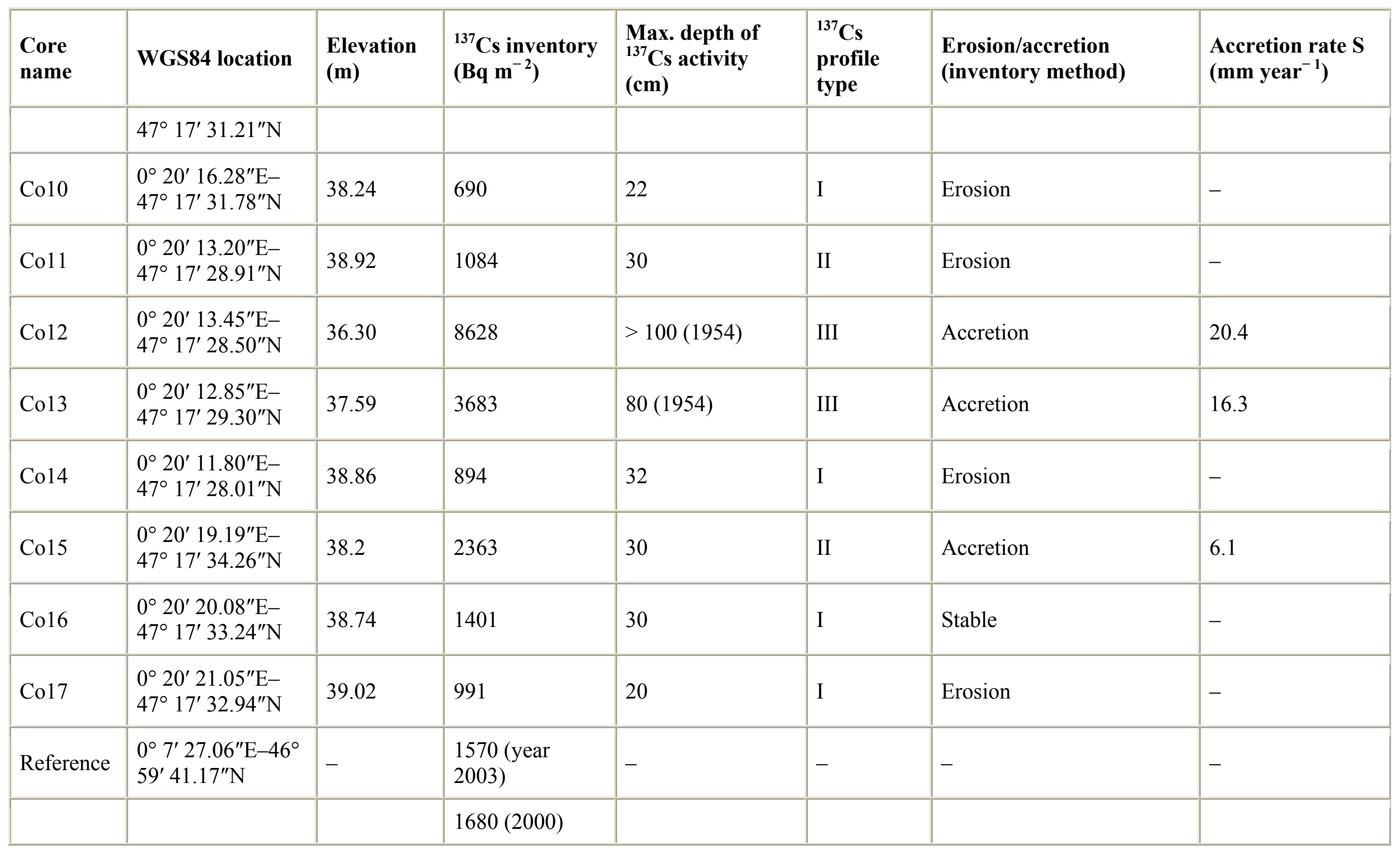


Table 2.

Activity of each grain size class of three highly active heterometric samples; Co18 location is shown in Fig. 1B.

\begin{tabular}{|c|c|c|c|c|c|c|}
\hline \multirow[t]{2}{*}{ Sample (core-increment) } & \multicolumn{2}{|c|}{ Co4 75-88 } & \multicolumn{2}{|c|}{ Co6 10-20 } & \multicolumn{2}{|c|}{ Co18 00-07 } \\
\hline & $\begin{array}{l}\text { Content } \\
(\%)\end{array}$ & $\begin{array}{l}{ }^{137} \mathrm{Cs} \text { activity (Bq } \\
\left.\mathrm{kg}^{-1}\right)\end{array}$ & $\begin{array}{l}\text { Content } \\
(\%)\end{array}$ & $\begin{array}{l}{ }^{137} \mathrm{Cs} \text { activity (Bq } \\
\left.\mathrm{kg}^{-1}\right)\end{array}$ & $\begin{array}{l}\text { Content } \\
(\%)\end{array}$ & $\begin{array}{l}{ }^{137} \mathrm{Cs} \text { activity (Bq } \\
\left.\mathrm{kg}^{-1}\right)\end{array}$ \\
\hline Gravels (G) & 0 & 0 & 0.6 & 0 & 4.2 & 0 \\
\hline Fine sands (FS) & 11.8 & 6.8 & 29.2 & 3.5 & 4.7 & 16.2 \\
\hline Silts + clays $(F)$ & 61.9 & 18.9 & 19.5 & 41.6 & 38.8 & 43.5 \\
\hline $\begin{array}{l}\text { Recalculated activity (Bq } \\
\left.\mathrm{kg}^{-1}\right)\end{array}$ & & 12.98 & & 9.93 & & 19.74 \\
\hline
\end{tabular}


